\title{
Triiodothyronine Radioimmunoassay
}

\author{
JEFFREY LIEBLICH and RoBerT D. UTIGER \\ From the Endocrine Section, Department of Medicine, University of Pennsylvania \\ School of Medicine, Philadelphia, Pennsylvania 19104
}

A в S T R A C T Highly specific antisera to triiodothyronine $\left(\mathrm{T}_{3}\right)$ were prepared by immunization of rabbits with $T_{3}$-bovine serum albumin conjugates. Antisera with $\mathrm{T}_{3}$ binding capacity of up to $600 \mathrm{ng} / \mathrm{ml}$ were obtained. The ability of various thyronine derivatives to inhibit the binding of $\mathrm{T}_{3}{ }^{125} \mathrm{I}$ to anti- $\mathrm{T}_{3}$ serum was found to vary considerably. L-T, $\mathrm{D}_{3} \mathrm{~T}_{3}$ and several triiodoanalogues were potent inhibitors of the reaction. Little inhibition of $\mathrm{T}_{3}{ }^{125} \mathrm{I}$ binding was produced by L-thyroxine $\left(T_{4}\right)$ or other tetraiodo- analogues, thyronine or iodotyrosines. Chromatography of several $T_{4}$ preparations indicated that most of their very slight activity could be ascribed to contamination with $\mathrm{T}_{3}$.

Successful assay of $T_{3}$ in serum was accomplished by the addition of diphenylhydantoin to the assay system. Under these circumstances, recovery of $T_{8}$ added to serum was excellent, and addition of $T_{4}$ was without significant effect. Serum $T_{3}$ concentrations in normal subjects averaged $145 \pm 25 \mathrm{ng} / 100 \mathrm{ml}(\mathrm{sD})$. Increased concentrations ( $429 \pm 146 \mathrm{ng} / 100 \mathrm{ml})$ were observed in hyperthyroid patients whereas those with hypothyroidism had serum $T_{3}$ levels of $99 \pm 24 \mathrm{ng} / 100 \mathrm{ml}$. Elevated $T_{3}$ concentrations were found also in hypothyroid patients receiving $25 \mu \mathrm{g}$ or more of $\mathrm{T}_{3}$ daily and in those receiving $300 \mu \mathrm{g}$ of $\mathrm{T}_{4}$ daily. Serial measurements of $\mathrm{T}_{3}$ concentrations in subjects after oral $T_{3}$ administration revealed peak $\mathrm{T}_{3}$ concentrations $2-4 \mathrm{hr}$ after $\mathrm{T}_{3}$ administration. Intramuscular administration of thyrotropin (TSH) resulted in earlier and more pronounced increases in serum $T_{3}$ than in serum $T_{4}$ concentrations.

Triiodothyronine $\left(T_{3}\right)^{1}$ was recognized to be a biologically active secretory product of the thyroid gland over a decade ago (1). Recent studies have indicated that it is formed extrathyroidally as well $(2,3)$. Nevertheless, relatively little information concerning the role of $T_{3}$ secretion in different thyroid disorders has

\footnotetext{
Received for publication 5 April 1971 and in revised form 13 August 1971.

1 Abbreviations used in this paper: BSA, bovine serum albumin; HSA, human serum albumin; PBI, protein bound iodine; $T_{3}$, triiodothyronine; $T_{4}$, thyroxine; $T B G$, thyroxine binding globulin; TSH, thyrotropin.
}

been accumulated until very recently. Methods for the measurement of $T_{3}$ which require its extraction from plasma, and often its separation from thyroxine as well, have been described by several investigators (4-11). These methods have proven useful, but they are relatively complicated, the number of samples that can be assayed is limited, and they may be affected by in vitro deiodination of thyroxine. More recently the radioimmunoassay technique has been applied to the measurement of $T_{3}$. Several preliminary reports have appeared describing the preparation of antibody to triiodothyronine by immunization of animals with $\mathrm{T}_{3}$-protein conjugates and its use for the measurement of $T_{3}$ in serum (12-15). The present report describes the development of a radioimmunoassay for the measurement of $T_{3}$, studies of the specificity of the anti- $\mathrm{T}_{3}$ serum, and some initial studies which indicate that the method is applicable to the measurement of $T_{3}$ in unextracted serum.

\section{METHODS}

Materials. L-Triiodothyronine $\left(\mathrm{T}_{3}\right)$ was obtained from

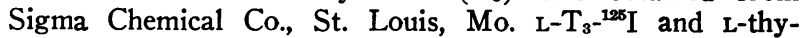
roxine- ${ }^{125} \mathrm{I}$ with specific activities of $50 \mathrm{mCi} / \mathrm{mg}$ or greater were obtained from Abbott Laboratories, Chemical Marketing Div., North Chicago, Ill. Various thyroid analogues were obtained from Sigma or provided through the courtesy of Dr. Leonard Ginger of Baxter Laboratories, Inc., Morton Grove, Ill. Bovine serum albumin (BSA) was obtained from Nutritional Biochemicals Corporation, Cleveland, Ohio, and human serum albumin (HSA) from Armour Pharmaceutical Co., Chicago, I1l. and Hyland Laboratories, Los Angeles, Calif.

Preparation of $T_{s}$-bovine serum albumin conjugates. The immunogen used was prepared by coupling $\mathrm{T}_{3}$ to $\mathrm{BSA}$ with a water-soluble carbodiimide. In the three conjugate preparations made, $40 \mathrm{mg}$ of $\mathrm{T}_{3}$ was dissolved in $2 \mathrm{ml} 0.1 \mathrm{~N}$ $\mathrm{NaOH}$. To this was added $20 \mathrm{mg} \mathrm{BSA}$ in $3 \mathrm{ml}$ water and then $200 \mathrm{mg}$ 1-ethyl-3-(3-dimethylaminopropyl)-carbodiimide $\mathrm{HCl}$. The $\mathrm{pH}$ of the reaction was adjusted to 9.0 with $0.1 \mathrm{~N} \mathrm{HCl}$. The mixture was stirred at $5^{\circ} \mathrm{C}$ for $24 \mathrm{hr}$ and subsequently dialyzed for $96 \mathrm{hr}$ against water and finally for $24 \mathrm{hr}$ against $0.15 \mathrm{M} \mathrm{NaCl}$. Conjugates of BSA alone or BSA and L-thyroxine $\left(T_{4}\right)$ were prepared in a similar manner.

The final product of these reactions was analyzed for protein by the method of Lowry, Roseborough, Farr, and 
TABLE I

Characteristics of $T_{3}$-Albumin Conjugates

\begin{tabular}{|c|c|c|c|c|c|}
\hline & \multirow{2}{*}{$\begin{array}{c}\begin{array}{l}\text { Pro- } \\
\text { tein }\end{array} \\
\mathrm{mg} / \mathrm{ml}\end{array}$} & \multicolumn{2}{|c|}{ PBI* } & \multirow{2}{*}{$\begin{array}{c}\begin{array}{c}\mathrm{T}_{3} \\
\text { Immuno- } \\
\text { assay }\end{array} \\
\mu g T_{3} / m g\end{array}$} & \multirow{2}{*}{$\begin{array}{c}\begin{array}{c}\mathrm{T}_{8} / \\
\text { albumin }\end{array} \\
\text { moles/mol }\end{array}$} \\
\hline & & $\mu g / m g$ & $\mu g T_{3} / m g$ & & \\
\hline $\mathrm{T}_{3}$-BSA (1) & 4.3 & 18.2 & 31.2 & 21.2 & 1.82 \\
\hline $\mathrm{T}_{3}$-BSA (3) & 4.8 & 34.4 & 59.0 & 76.1 & 6.60 \\
\hline $\mathrm{T}_{3}$-BSA (3) & 4.5 & 一 $\ddagger$ & - & 39.4 & 3.38 \\
\hline $\mathrm{T}_{3}$-BSA (4) & 5.3 & - & - & 78.8 & 6.78 \\
\hline BSA & 5.0 & $<0.02$ & $<0.04$ & $<0.013$ & $<0.002$ \\
\hline $\mathrm{T}_{4}$-BSA & 5.2 & - & - & 0.29 & 0.021 \\
\hline
\end{tabular}

* Measured by the autoanalyzer method.

$\ddagger$ The symbol $(-)$ means not measured.

Randall (16), for protein bound iodide (PBI) by the autoanalyzer technique and ultimately in the $\mathrm{T}_{3}$ radioimmunoassay. The results of these analyses (Table I) indicate that significant conjugation of $T_{3}$ to albumin had occurred, the calculated $\mathrm{T}_{3}$ to BSA molar ratios of the $\mathrm{T}_{3}$-BSA conjugates ranging from 1.82-6.78:1. The reason for this variability is not known. Since good agreement was found between the $T_{3}$ content of the preparations calculated from the PBI data and from the immunoassay results (Table I), it was concluded that little deiodination of $T_{3}$ had occurred during the preparation of the conjugates.

Preparation and detection of anti-Ts antibody. Rabbits were immunized by foot pad injection of $0.4-0.8 \mathrm{mg} \mathrm{T} \mathrm{T}_{\mathbf{3}^{-}}$ BSA conjugate emulsified in $0.75-1.0 \mathrm{ml}$ complete Freund's adjuvant at monthly intervals. Sera were obtained before each booster injection and stored at $-5^{\circ} \mathrm{C}$. Sera obtained after the first injection of conjugate were found to contain some anti- $T_{3}$ antibody but those obtained after three to four injections had a much greater quantity of antibody and were used exclusively in the studies to be described. Initially, four animals were immunized and most of the studies herein reported were done using serum obtained following the third injection of one of these animals. Subsequently, additional animals have been immunized and additional anti-sera of similar potency and affinity obtained. Micro agar gel diffusion studies showed a single precipitin line when anti- $T_{3}$ sera were reacted with $T_{3}$-BSA and BSA treated with carbodiimide and a line of identity was observed when the antigens were placed in adjacent wells. No precipitin lines were seen between wells containing unmodified BSA and anti- $\mathrm{T}_{3}$ serum.

Antibody to $T_{3}$ was detected by reaction of $0.04-0.08 \mathrm{ng}$ $T_{3}{ }^{125} \mathrm{I}$ with varying quantities of anti- $\mathrm{T}_{3}$ antibody for $24-48$ $\mathrm{hr}$ and then separation of free and antibody bound $\mathrm{T}_{3}{ }^{-125} \mathrm{I}$ by addition of goat anti-rabbit IgG serum. With potent anti$\mathrm{T}_{3}$ sera as little as $0.5 \mu 1$ bound $90 \%$ of the $\mathrm{T}_{8^{1}}{ }^{125} \mathrm{I}$ added. The binding capacity of the most potent antiserum obtained, estimated by addition of $0.04-4.2 \mathrm{ng}$ quantities of $\mathrm{T}_{3}{ }^{-125} \mathrm{I}$ to antiserum diluted such that $40-60 \%$ of the radioactivity

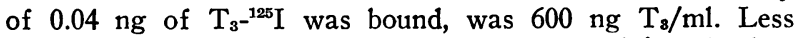
than $2.5 \%$ of the radioactivity added was precipitated when $\mathrm{T}_{3^{-}}{ }^{125} \mathrm{I}$ was reacted with normal rabbit serum.

Radioimmunoassay of $T_{s}$. For $T_{3}$ assay duplicate tubes containing the following reagents were prepared: $(a) 100$ $\mu 1$ of unlabeled $\mathrm{T}_{3}$ diluted in $4 \% \mathrm{HSA}, 0.05 \mathrm{M}$ phosphate, $\mathrm{pH} 8.0$, or the serum to be assayed. Serum samples were always tested in at least two doses, usually 50 and $100 \mu 1$.
When serum volumes of less than $100 \mu$ l were used, albumin-phosphate buffer was added to bring the volume to $100 \mu 1$. The concentrated human albumin solution was used to approximately equalize the protein concentration in each tube. (b) $50 \mu \mathrm{l} \mathrm{T}_{3^{-}}{ }^{125} \mathrm{I}(0.04-0.08 \mathrm{ng}$, approximately 3000 $6000 \mathrm{dpm}$ ) in $0.25 \% \mathrm{BSA}, 0.05 \mathrm{~m}$ phosphate $\mathrm{pH} 8.0$, containing $1.0 \mathrm{mg} / \mathrm{ml}$ diphenylhydantoin. To ensure solubility of the diphenylhydantoin, this solution was adjusted to $\mathrm{pH}$ 10.2-10.4 with $\mathrm{NaOH}$. The $\mathrm{pH}$ of the complete reaction mixture was 8.2-8.3. (c) $50 \mu \mathrm{l}$ anti- $\mathrm{T}_{3}$ serum diluted so that $40-60 \%$ of the added $\mathrm{T}_{3^{-125}} \mathrm{I}$ was precipitated in the absence of unlabeled $\mathrm{T}_{3}$. The buffer used for the anti-serum dilution was $0.25 \%$ BSA, $0.05 \mathrm{M}$ phosphate, $\mathrm{pH} 8.0$. containing 0.05 M EDTA. With the anti- $\mathrm{T}_{3}$ serum used in most of these studies, this dilution was $1: 200$.

After $48 \mathrm{hr}$ at $5^{\circ} \mathrm{C}$, goat anti-rabbit IgG serum was added in sufficient quantity to precipitate all the rabbit $\operatorname{IgG}$ present. The presence of human IgG (in serum) or addition of purified human IgG to solutions of $T_{3}$ in buffer did not require the addition of larger quantities of anti-rabbit IgG serum. Subsequent to an additional $18-24 \mathrm{hr}$ at $5^{\circ} \mathrm{C}$, the tubes were centrifuged at $1000 \mathrm{~g}$ and the radioactivity in the precipitate determined. Shorter periods of incubation of the $T^{{ }^{1}{ }^{125} \mathrm{I}}$ and anti- $\mathrm{T}_{3}$ serum resulted in reduced binding of $\mathrm{T}_{{ }^{3}}{ }^{125} \mathrm{I}$ to antibody. The proportion of radioactivity precipitated in duplicate tubes rarely varied by greater than $2 \%$. When anti- $\mathrm{T}_{3}$ antibody and/or anti-rabbit IgG were omitted from the reaction mixture, no more than $1.5 \%$ of the total radioactivity was precipitated.

Fractionation studies. Several fractionation procedures were employed in the course of these studies. For the purpose of determining the $T_{3}$ content of various $T_{4}$ preparations, 10-20 $\mu \mathrm{g}$ quantities of $\mathrm{T}_{4}$ were chromatographed on $1 \times 50 \mathrm{~cm}$ columns of Sephadex G-25 (Pharmacia Fine Chemicals, Inc., Piscataway, N. J.) in $0.01 \mathrm{~N} \mathrm{NaOH}$ as described by Mougey and Mason (17). With the use of $\mathrm{T}_{3^{-}}$ ${ }^{125} \mathrm{I}$ and $T_{4}{ }^{-125} \mathrm{I}$, it was found that $T_{3}$ and $T_{4}$ were separated satisfactorily by this procedure, $\mathrm{T}_{3}$ emerging from the column well before $T_{4}$. When unlabeled $T_{4}$ was applied to these columns, fractions corresponding to the $T_{3}$ peak and the $T_{4}$ peak, as determined by radioactivity calibration in preceding runs, were pooled, neutralized with $0.1 \mathrm{~N}$ acetic acid, and lyophilized. The lyophilized fractions were reconstituted in 1-2 $\mathrm{ml}$ for $T_{3}$ immunoassay and $T_{4}$ assay by the competitive protein binding procedure (18). In several instances, one-half of the $\mathrm{T}_{4}$ fraction from such a chromatographic separation was rerun on the Sephadex G-25 in the same manner.

Three methods for the extraction of thyroid hormones from serum were used. One employed chromatography of serum on the cation exchange resin Dowex AG $50 \mathrm{~W}-\mathrm{X} 2$ ( $\mathrm{H}+$ form) (Dow Chemical Co., Midland, Mich.) as described by Sterling, Bellabarba, Newman, and Brenner (8). The fraction containing both the unabsorbed serum and $0.15 \mathrm{~m}$ ammonium acetate, $\mathrm{pH} 8.5$, which was passed through the column immediately after the serum, was lyophilized and subsequently reconstituted to the initial serum volume with $0.01 \mathrm{M}$ phosphate, $0.15 \mathrm{M} \mathrm{NaCl}, \mathrm{pH}$ 7.5. The $\mathrm{T}_{3}$ was eluted with $7.4 \mathrm{~N} \mathrm{NH} \mathrm{NH}_{4} \mathrm{OH}$. This fraction was evaporated to dryness at $70^{\circ} \mathrm{C}$ and reconstituted to the initial serum volume with $4 \%$ HSA, $0.05 \mathrm{~m}$ phosphate, $\mathrm{pH} 8.0$.

Thyroid hormones were also extracted from serum by ethanol precipitation. 1 volume of serum and 2 volumes of $95 \%$ ethanol were mixed, centrifuged at $1000 \mathrm{~g}$, and samples of the resulting supernatant dried at $40^{\circ} \mathrm{C}$ under an air stream. In several experiments, the initial ethanol precipi- 


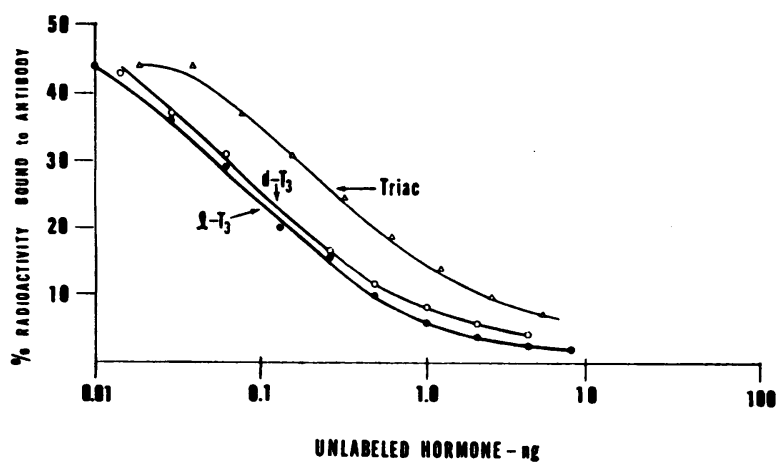

FIGURE 1 The effect of increasing quantities of unlabeled $L-T_{3}$ and $T_{8}$ analogues on the binding of $T_{3^{-}}{ }^{125} \mathrm{I}$ to anti- $T_{8}$ serum. Triac, triiodothyroacetic acid.

tates were recovered for immunoassay by suspension in water, dialysis, and lyophilization. The dried supernatants were suspended in a volume of $4 \% \mathrm{HSA}, 0.05 \mathrm{M}$ phosphate, $\mathrm{pH}$ 8.0, equal to the initial serum content of the dried extract. They were then centrifuged and a sample of the resulting supernatant tested in the $T_{3}$ immunoassay. The centrifugation step was included because the resuspended dried ethanol extracts contained varying quantities of particulate material. This particulate material was found to bind irreversibly, in the absence of anti- $\mathrm{T}_{3}$ or second antibody, a variable quantity of $\mathrm{T}_{\mathbf{3}^{-}}{ }^{125} \mathrm{I}(4.5-24.7 \%)$ when incubated with it and the reaction mixture sedimented at the usual centrifugation speed $(1000 \mathrm{~g})$. This was not reduced by centrifugation of the initial serum-ethanol mixture at $10,000 \mathrm{~g}$. When $\mathrm{T}_{\mathbf{3}^{-}}{ }^{125} \mathrm{I}$ was added to serum before the ethanol precipitation, $95.4 \pm 3.1 \%$ (SD) of the added radioactivity could be recovered after resuspension of the dried supernatants. Of this radioactivity, however, 18.6-37.2\% (mean 26.0, $\mathrm{n}=9$ ) sedimented at $1000 \mathrm{~g}$.

$\mathrm{T}_{3}$ was also extracted from serum to which diphenylhydantoin, in a final concentration of $500 \mu \mathrm{g} / \mathrm{ml}$, had been added by treatment three times with Tetrasorb resin sponges (Abbott Laboratories, North Chicago, Ill.).

Clinical material. Serum was obtained from patients hospitalized on the Medical Service or the Clinical Research Center at the Hospital of the University of Pennsylvania or the Philadelphia Veterans Administration Hospital and from patients who were attending the Endocrine Clinic of the University Hospital. The hyperthyroid patients studied all had typical clinical and laboratory manifestations of hyperthyroidism. Each patient considered to be hypothyroid had signs and symptoms compatible with this diagnosis and, in addition, a low serum $\mathrm{T}_{4}$ concentration, as determined by the competitive protein binding method (18). Of the 45 hypothyroid patients studied, 42 had elevated serum immunoreactive TSH concentrations (19), ranging from 10.8 to $2350 \mu \mathrm{U} / \mathrm{ml}$. The remaining three patients all had serum $\mathrm{T}_{4}$ concentrations below $2.4 \mu \mathrm{g} / 100 \mathrm{ml}$ and undetectable or barely detectable TSH levels. After separation, serum samples were stored at $-5^{\circ} \mathrm{C}$.

\section{RESULTS}

Antibody specificity studies. Results of studies showing the ability of unlabeled $\mathrm{T}_{3}$ and various analogues of it to inhibit the binding of $\mathrm{T}_{3-}{ }^{125} \mathrm{I}$ to antibody are shown in Figs. 1 and 2. Addition of both $T_{s}$ and various thyroid analogues resulted in progressive reduction in the proportion of $\mathrm{T}_{{ }_{3}-}{ }^{125} \mathrm{I}$ bound to antibody. The dose response lines produced by $\mathrm{T}_{3}$ and the compounds studied were similar in all instances. Significant inhibition of $\mathrm{T}_{3^{-}}{ }^{125} \mathrm{I}$ binding to antibody occurred with as little as 0.05 ng unlabeled $T_{3}$. Multiple preparations of $T_{3}$ were tested and no significant differences among them were observed. It is apparent from Fig. 1 that the two triiodoanalogues shown were nearly as effective as $\mathrm{L}^{-\mathrm{T}_{3}}$ in inhibiting the binding of $\mathrm{T}_{3}-\mathrm{I}^{125}$ to antibody, the most potent being $\mathrm{D}-\mathrm{T}_{\mathrm{s}}$. In contrast, the tetraiodo- analogues tested were effective only when much larger quantities were added (Fig. 2). Table II shows the potency, on a weight basis, of all of the various compounds tested compared to that of unlabeled $T_{8}$. Each was tested in multiple doses in at least two assays. As indicated in the table, several L-thyroxine preparations were tested. All inhibited the binding of $\mathrm{T}_{3^{-}}{ }^{125} \mathrm{I}$ to antibody when added in large quantities but their potency varied considerably. Contamination of the $T_{4}$ preparations with $T_{3}$ was known in some instances, but said to be absent by the manufacturer in others. The preparations were indistinguishable when tested in the competitive displacement assay for $T_{4} . T_{3}$ and $T_{4}$ were tested in reaction

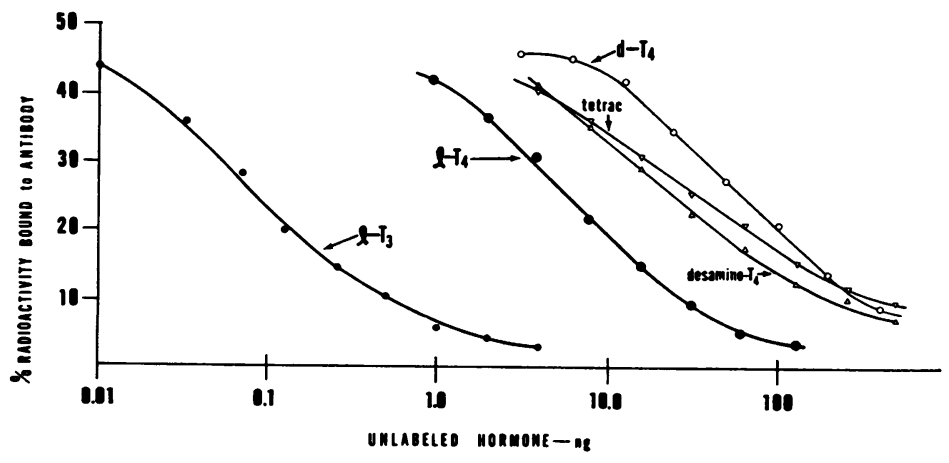

Figure 2 The effect of unlabeled $T_{t}$ and various $T_{t}$ analogues on the binding of $T_{\mathbf{3}^{-}}{ }^{125} \mathrm{I}$ to anti-T $\mathrm{T}_{\mathbf{3}}$. Tetrac, tetraiodothyroacetic acid. 
TABLE II

Thyronine Derivative Cross-Reactivity in $T_{3}$ Immunoassay

\begin{tabular}{|c|c|}
\hline Compound & $\begin{array}{l}\text { Cross- } \\
\text { reactivity }\end{array}$ \\
\hline & $\%$ \\
\hline L-triiodothyronine & 100.0 \\
\hline D-triiodothyronine* & 81.8 \\
\hline D-triiodothyronine $\ddagger$ & 89.5 \\
\hline Triiodothyroacetic acid* & 31.5 \\
\hline Triiodothyropropionic acid* & 52.7 \\
\hline L-thyroxine* & 0.14 \\
\hline L-thyroxine $\ddagger$ & 0.45 \\
\hline L-thyroxine* & 0.52 \\
\hline L-thyroxine $\ddagger$ & 0.62 \\
\hline L-thyroxine* & 1.34 \\
\hline D-thyroxine $f$ & 0.10 \\
\hline D-thyroxine* & 0.16 \\
\hline Tetraiodothyroacetic acid $\ddagger$ & 0.16 \\
\hline Tetraiodothyroacetic acid* & 0.26 \\
\hline Desaminothyroxine* & 0.36 \\
\hline Monoiodotyrosine* & $<0.0001$ \\
\hline Diiodotyrosine* & $<0.0001$ \\
\hline L-3,5-diiodothyronine $\ddagger$ & 0.094 \\
\hline DL-thyronine $\ddagger$ & $<0.0012$ \\
\hline
\end{tabular}

* Obtained from Sigma Chemical Co., St. Louis, Mo.

‡ Baxter Laboratories, Inc., Morton Grove, Ill.

mixtures employing other buffers ranging in $\mathrm{pH}$ from 5.2 to 9.2 with similar results.

Results of $T_{3}$ immunoassay and $T_{4}$ analysis of the fractions obtained by Sephadex chromatography of several T* preparations are shown in Table III. Similar analyses of the $T_{4}$ preparations subjected to chromatography are also shown. In experiment 1 , the $T_{4}$ fraction from the column contained the equivalent of $0.17 \% \quad \mathrm{~T}_{3}$ (1.7 $\mathrm{ng}$ $\left.\mathrm{T}_{8} / 1 \mu \mathrm{g} \mathrm{T}_{4}\right)$. The $\mathrm{T}_{4}$ fraction in the second experiment

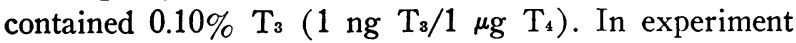
3 , the $\mathrm{T}_{4}$ fraction after the initial chromatography contained $0.03 \% \mathrm{~T}_{3}$. Repurification of this $\mathrm{T}_{4}$ fraction

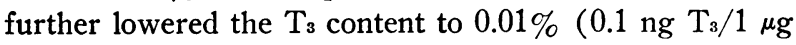
$T_{4}$ ). These results indicate that the reactivity of $T_{4}$ with anti- $T_{3}$ serum can be largely attributed to $T_{3}$ contamination. The very slight $T_{3}$ immunoreactivity of the twice purified $T_{4}$ could be due to the presence of small amounts of $T_{3}$ generated from $T_{4}$ during the fractionation procedure or might represent very slight intrinsic reactivity of $T_{4}$ with anti- $\mathrm{T}_{3}$ serum.

The reactivity of $T_{3}-B S A$ and other conjugates in the immunoassay was also examined. Both $\mathrm{T}_{3}-\mathrm{BSA}$ and T4-BSA conjugates inhibited the binding of $\mathrm{T}_{3}{ }^{-25} \mathrm{I}$ to antibody, though the activity of the $\mathrm{T}_{4}-\mathrm{BSA}$ conjugate was minimal (Table I). The dose response pattern of the conjugate inhibition was similar to that of $\mathrm{T}_{3}$ alone. The carbodiimide treated albumin did not inhibit $\mathrm{T}_{3}{ }^{125} \mathrm{I}$ binding to antibody in doses up to $0.5 \mathrm{mg}$. Both human and bovine albumin preparations also slightly inhibited the reaction when tested in doses of $5-30 \mathrm{mg}$.

Assay of $T_{s}$ in serum. Initial attempts to determine the $T_{3}$ concentration in serum in incubation mixtures not containing diphenylhydantoin yielded values of 300 $\mathrm{ng} / 100 \mathrm{ml}$ or higher in most instances and these values bore little relation to the quantity expected considering the clinical status of the patient. Furthermore, with many samples little dose response effect was evident when varying quantities of serum were tested. Since in all instances the amount of $\mathrm{T}_{3^{-}}{ }^{125} \mathrm{I}$ bound to antibody when serum was added was low, these results suggested that $\mathrm{T}_{3}{ }^{125} \mathrm{I}$ was reacting with the thyroxine binding globulin (TBG) in serum and thus was not available for binding to anti- $T_{3}$ antibody. The addition of diphenylhydantoin, a known competitive inhibitor of the binding of thyroxine to TBG (20-23), was found to prevent this. Addition of diphenylhydantoin in albumin solution in doses up to $200 \mu \mathrm{g} /$ tube did not inhibit the binding of $\mathrm{T}_{3}{ }^{125} \mathrm{I}$ to antibody or alter the sensitivity of the system to unlabeled $\mathrm{T}_{3}$. When added in increasing quantities to different serum samples, the proportion of $\mathrm{T}_{{ }_{3}-}{ }^{225} \mathrm{I}$ bound to antibody gradually increased until a plateau was reached (Fig. 3). These findings indicate that these quantities of diphenylhydantoin prevent binding of $\mathrm{T}_{3-}{ }^{125} \mathrm{I}$ to $\mathrm{TBG}$ and allow reaction of the endogenous serum $T_{3}$ with anti- $T_{3}$ serum. In other experiments the effect of diphenylhydantoin in doses up to $200 \mu \mathrm{g} /$ tube was studied. The results were similar to those observed when 25 or $50 \mu \mathrm{g} /$ tube was used. On the basis of these results a dose of 50

TABLE III

$T_{3}$ and $T_{4}$ in Fractions after Gel Filtration of $T_{4}$

\begin{tabular}{|c|c|c|c|}
\hline & $\mathrm{T}_{3}$ & $T_{4}$ & $\mathrm{~T}_{3} / \mathrm{T}_{4}$ \\
\hline \multicolumn{4}{|l|}{ Experiment 1} \\
\hline $\mathrm{T}_{4}$ & 80.0 & 15.00 & 6.0 \\
\hline " $\mathrm{T}_{3}$ " fraction & 60.8 & 0.19 & 320.0 \\
\hline "T $\mathrm{T}_{4}$ " fraction & 16.3 & 9.85 & 1.7 \\
\hline \multicolumn{4}{|l|}{ Experiment 2} \\
\hline $\mathrm{T}_{4}$ & 28.8 & 16.7 & 1.7 \\
\hline " $\mathrm{T}_{3}$ " fraction & 20.5 & 0.64 & 33.8 \\
\hline " $T_{4}$ " fraction & 12.6 & 12.60 & 1.0 \\
\hline \multicolumn{4}{|l|}{ Experiment 3} \\
\hline \multicolumn{4}{|l|}{ First column } \\
\hline$T_{4}$ & 57.4 & 20.0 & 2.9 \\
\hline " $\mathrm{T}_{3}$ " fraction & 25.2 & 0.15 & 164.0 \\
\hline " $\mathrm{T}_{4}$ " fraction & 3.0 & 9.0 & 0.3 \\
\hline \multicolumn{4}{|l|}{ Second column } \\
\hline " $\mathrm{T}_{3}$ " fraction & 0.7 & 0.09 & 0.8 \\
\hline " $\mathrm{T}_{4}$ " fraction & 0.8 & 7.6 & 0.1 \\
\hline
\end{tabular}




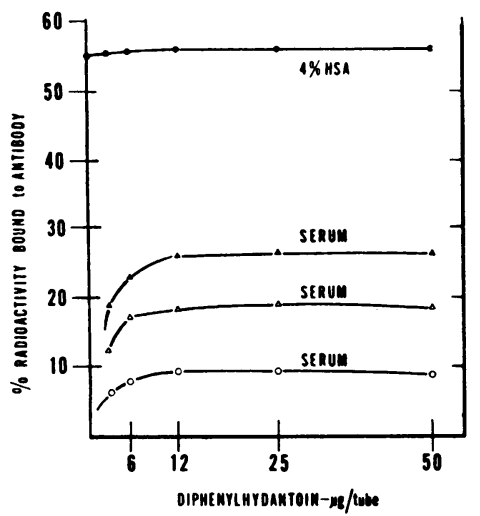

FIGURE 3 The effect of addition of increasing quantities of diphenylhydantoin to several different serum samples and $4 \% \mathrm{HSA}$ on the binding of $\mathrm{T}_{3^{-}}{ }^{125} \mathrm{I}$ to anti-T $\mathrm{T}_{3}$ serum.

$\mu \mathrm{g} /$ tube was chosen for regular use. Under these conditions, the pattern of inhibition of binding of $\mathrm{T}_{3}{ }^{-25} \mathrm{I}$ to antibody produced by varying doses of serum was similar to that produced by unlabeled $\mathrm{T}_{3}$ (Fig. 4). Hypothyroid serum treated with resin sponges as outlined above did not inhibit the reaction in the presence of diphenylhydantoin whereas significant inhibition of $\mathrm{T}_{3-}{ }^{125} \mathrm{I}$ binding to anti-Ts occurred in the absence of diphenylhydantoin.

Effect of added $T_{4}$ and $T_{s}$ on serum $T_{\text {s }}$ concentrations. Although the studies with the $T_{3}$ analogues showed that the anti- $T_{3}$ serum was highly specific and suggested that most of the $T_{4}$ cross-reactivity observed was due to $T_{3}$ contamination, the effect of addition of $T_{4}$ to serum on the immunoassayable $T_{3}$ concentration was studied. The $T_{4}$ preparation available which had the least crossreactivity in the $\mathrm{T}_{\mathrm{s}}$ immunoassay was used (Table II). The results are shown in Table IV. For these studies, multiple serum samples of widely varying endogenous $T_{3}$ and $T_{4}$ concentrations were used. When $T_{4}$ in a con-

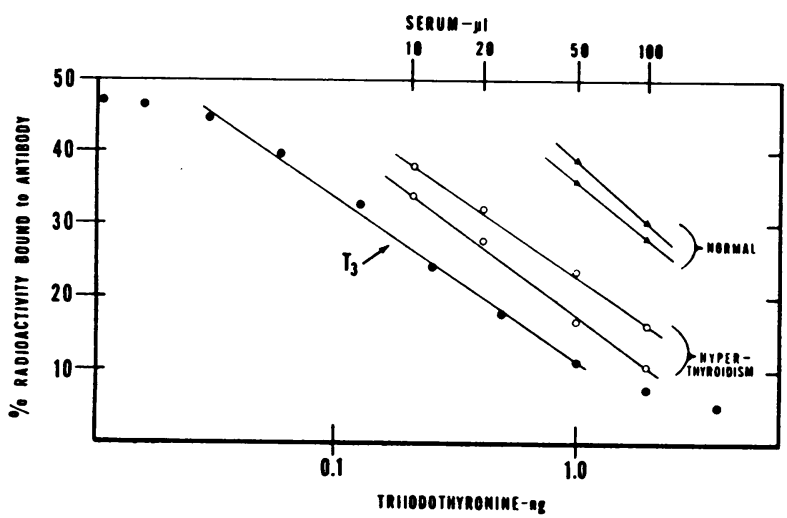

Figure 4 Standard assay curve and pattern of inhibition of $\mathrm{T}_{8^{-}}{ }^{125} \mathrm{I}$ binding to antibody produced by different doses of several serum samples.
TABLE IV

Effect of Added $T_{4}$ on Serum $T_{3}$ Concentrations

\begin{tabular}{ccc}
\hline T, added & No. & Effect of $\mathrm{T}_{4}$ \\
\hline$\mu g / 100 \mathrm{ml}$ & & $\begin{array}{c}\text { \% unmodified serum } \\
\text { result } \pm \mathrm{SD}\end{array}$ \\
& & $102.0 \pm 4.2$ \\
25.0 & 11 & $107.9 \pm 11.3$ \\
50.0 & 21 & $121.3 \pm 16.9$ \\
100.0 & 12 & \\
\hline
\end{tabular}

centration of $25 \mu \mathrm{g} / 100 \mathrm{ml}$ was added, the mean serum $\mathrm{T}_{3}$ concentration was $102 \pm 4.2 \%$ (SD) of the unmodified serum result. At added $T_{4}$ concentrations of 50 and 100 $\mu \mathrm{g} / 100 \mathrm{ml}$, the mean serum $\mathrm{T}_{3}$ values were $107.9 \pm 11.3 \%$ and $121.3 \pm 16.9 \%$ of the unmodified serum results, respectively. Thus, it is clear that $T_{t}$ in serum in any quantity likely to be encountered clinically would not artifactually elevate the serum $T_{8}$ level as measured in this system.

In Table $\mathrm{V}$ are shown the results of serum assays after the addition of unlabeled $T_{3}$. Serum from normal, hypothyroid, hyperthyroid, and estrogen-treated subjects was enriched with $T_{3}$ in concentrations ranging from 31.2 to $500 \mathrm{ng} / 100 \mathrm{ml}$ (usually in quantities ranging from 0.015 to $0.250 \mathrm{ng} / 50 \mu \mathrm{l})$. In all instances the mean recovery was greater than $90 \%$. In one experiment, $T_{s}$ was reacted with serum for $24 \mathrm{hr}$ at $5^{\circ} \mathrm{C}$ before assay. Recovery values similar to those described above were found.

Reproducibility. The quantity of $\mathrm{T}_{\mathbf{3}}$ found to produce a $50 \%$ reduction in the quantity of radioactivity bound to anti-Ts antibody in 21 assays was $0.276 \pm 0.037 \mathrm{ng}$ (SD). Both intra- and interassay variability was examined repeatedly with samples of widely varying $T_{3}$ concentration. The mean coefficient of variation ( $\mathrm{SD} /$ mean $\times 100$ ) for 15 samples, each of which was assayed in two doses twice in the same assay, was $6.0 \pm 4.9 \%$ (SD). The mean coefficient of variation for 50 samples assayed in two doses from two to five times in different assays was $7.9 \pm 4.8 \%$ (SD). No differences in reproducibility were found in assays of serum containing low, normal, or high $\mathrm{T}_{3}$ concentrations.

TABLE $\mathrm{V}$

Recovery of $T_{3}$ Added to Serum

\begin{tabular}{ccc}
\hline T added & No. & Recovery \\
\hline$n g / 100 m l$ & & $\% \pm$ sD \\
31.2 & 6 & $95.7 \pm 4.1$ \\
62.5 & 12 & $92.5 \pm 6.9$ \\
125.0 & 16 & $95.8 \pm 12.2$ \\
250.0 & 15 & $96.8 \pm 7.4$ \\
500.0 & 14 & $102.5 \pm 9.2$ \\
\hline
\end{tabular}


TABLE VI

Serum $\mathrm{T}_{3}$ Concentrations

\begin{tabular}{lccr}
\hline \multicolumn{1}{c}{ Clinical status } & & $\mathrm{T}_{3}{ }^{*}$ & $\mathrm{~T}_{4} *$ \\
\hline & & $n g / 100 \mathrm{ml}$ & $\mu \mathrm{g} / 100 \mathrm{ml}$ \\
Normal & 79 & $145 \pm 25$ & $8.5 \pm 1.6$ \\
Hyperthyroidism & 36 & $429 \pm 146$ & $20.7 \pm 4.5$ \\
$\begin{array}{l}\text { Hypothyroidism } \\
\text { Pregnancy or }\end{array}$ & 45 & $99 \pm 24$ & $2.0 \pm 1.2$ \\
$\quad$ estrogen treatment & 20 & $186 \pm 32$ & $11.2 \pm 2.1$ \\
\hline
\end{tabular}

* Mean \pm SD.

Results of serum assays. The results of measurements of serum $T_{3}$ concentrations are shown in Table VI. Since the largest quantity of serum used was $100 \mu 1$ and usually $0.06 \mathrm{ng}$ unlabeled $\mathrm{T}_{3}$ produced significant inhibition of $\mathrm{T}_{{ }^{-}-}{ }^{125} \mathrm{I}$ binding to antibody, the minimum detectable $\mathrm{T}_{3}$ concentration was $60 \mathrm{ng} / 100 \mathrm{ml}$. In normal adult subjects serum $T_{3}$ concentrations ranged from 102 to $215 \mathrm{ng} / 100 \mathrm{ml}$. The mean ( $\pm \mathrm{SD}$ ) in the normal sera was $145 \pm 25$. No differences were found in serum $T_{3}$ results in males and females. In 10 normal subjects, $\mathrm{T}_{3}$ concentrations in serum collected on different days differed by an average of $20 \mathrm{ng} / 100 \mathrm{ml}$. In hyperthyroid patients serum $T_{3}$ concentrations ranged from 205 to $793 \mathrm{ng} / 100 \mathrm{ml}$, all values but one being higher than the highest of the normal serum $\mathrm{T}_{3}$ results. Serum $\mathrm{T}_{3}$ concentrations ranged from $<60$ to $136 \mathrm{ng} / 100 \mathrm{ml}$ in the patients with hypothyroidism; in three of these $\mathrm{T}_{3}$ levels $<60 \mathrm{ng} / 100 \mathrm{ml}$ were found. In the three patients with secondary hypothyroidism, serum $\mathrm{T}_{3}$ levels were 68,70 , and $115 \mathrm{ng} / 100 \mathrm{ml}$. The values were within two standard deviations of the normal mean in $52 \%$ of the hypothyroid patients. In pregnant women and patients receiving estrogen-containing medications, the mean serum $\mathrm{T}_{\mathrm{s}}$ concentration was $186 \mathrm{ng} / 100 \mathrm{ml}$.

Effects of thyroid hormones and TSH on serum $T_{s}$ concentrations. Serum $T_{3}$ concentrations in hypothyroid

TABLE VII

Serum $T_{3}$ and $T_{4}$ Concentrations in Thyroid Hormone Treated Patients

\begin{tabular}{lrcr}
\hline & No. & \multicolumn{1}{c}{$\mathrm{T}_{3} *$} & $\mathrm{~T}_{4} *$ \\
\hline & & $n g / 100 \mathrm{ml}$ & $\mu \mathrm{g} / 100 \mathrm{ml}$ \\
Normal & 79 & $145 \pm 25$ & $8.5 \pm 1.6$ \\
Thyroid treatment & & & \\
$25 \mu \mathrm{g} \mathrm{T} \mathrm{T}_{3} /$ day & 10 & $268 \pm 95$ & $3.3 \pm 1.2$ \\
$50 \mu \mathrm{g} \mathrm{T}_{3} /$ day & 8 & $371 \pm 169$ & $2.2 \pm 0.7$ \\
$75 \mu \mathrm{g} \mathrm{T}_{3} /$ day & 3 & $488 \pm 208$ & $3.1 \pm 1.5$ \\
$200 \mu \mathrm{g} \mathrm{T}_{4} /$ day & 16 & $169 \pm 32$ & $12.8 \pm 3.1$ \\
$300 \mu \mathrm{g} \mathrm{T} \mathrm{T}_{4} /$ day & 13 & $206 \pm 30$ & $15.7 \pm 3.6$ \\
\hline
\end{tabular}

$*$ Mean \pm sD. patients receiving various forms of replacement therapy are shown in Table VII. The $\mathrm{T}_{3}$-treated subjects had received therapy in the dosage shown for at least $1 \mathrm{wk}$; in all others the duration of therapy at the appropriate dose was 1 month before serum sampling. In the patients receiving $25 \mu \mathrm{g} \mathrm{T}_{3}$ daily, serum $\mathrm{T}_{3}$ levels ranged from 90 to $370 \mathrm{ng} / 100 \mathrm{ml}$. All of these patients had elevated TSH levels. Those receiving larger doses of $T_{3}$ had, with one exception, $T_{s}$ levels greater than $200 \mathrm{ng} /$ $100 \mathrm{ml}$ and most had TSH levels within the normal range. The range of values found in all of the $\mathrm{T}_{3}$-treated patients varied widely; this may be due to the fact that blood sampling was not done at any fixed interval after the last previous dose of medication (see below). In the patients receiving $200 \mu \mathrm{g} \mathrm{T}_{4}$ daily, serum $\mathrm{T}_{3}$ concentrations were usually within the normal range. Patients receiving $300 \mu \mathrm{g} \mathrm{T}_{4}$ daily had $\mathrm{T}_{3}$ concentrations ranging from 159 to $260 \mathrm{ng} / 100 \mathrm{ml}$. The mean value in this group, $206 \mathrm{ng} / 100 \mathrm{ml}$, differed significantly from the normal mean $(P<0.01)$. All of these patients were considered clinically euthyroid. In only one of the $\mathrm{T}_{4-}$ treated patients was a pretreatment serum $T_{3}$ value available. This clinically hypothyroid woman initially had a serum $T_{3}$ level of $122 \mathrm{ng} / 100 \mathrm{ml}$, a serum $\mathrm{T}_{4}$ of $1.0 \mathrm{\mu g} /$ $100 \mathrm{ml}$ and a serum TSH of $255 \mu \mathrm{U} / \mathrm{ml}$. The serum $\mathrm{T}_{3}$ concentration was $225 \mathrm{ng} / 100 \mathrm{ml}$ after 1 month and 159 $\mathrm{ng} / 100 \mathrm{ml}$ after 2 months of therapy with $\mathrm{T}_{4} 300 \mu \mathrm{g} /$ day in this patient.

Serial $T_{3}$ measurements were made after a single oral dose of $100 \mu \mathrm{g} \mathrm{T}_{3}$ in five normal subjects. The results of these studies are shown in Fig. 5. In each subject, the serum $\mathrm{T}_{3}$ concentration increased promptly, reached a peak 2-4 hr after $T_{s}$ administration, and then declined. The serum $T_{3}$ was slightly higher than control in each subject $24 \mathrm{hr}$ after the $\mathrm{T}_{3}$ administration. $\mathrm{T}_{3}$ in a dose of $200 \mu \mathrm{g}$ was given to two subjects after a similar protocol. The peak $\mathrm{T}_{3}$ values observed were $800 \mathrm{ng} /$

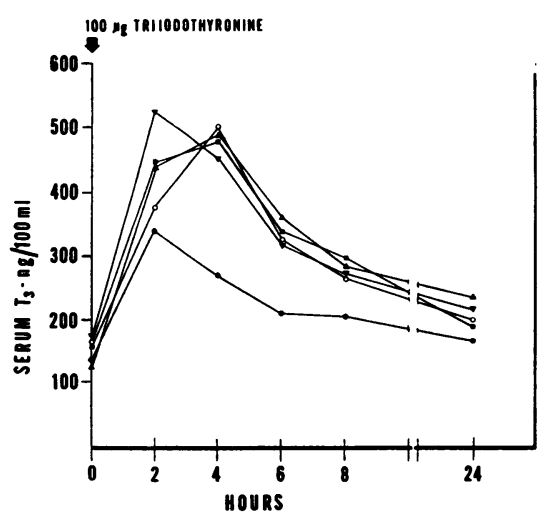

FIgURE 5 Serum $T_{3}$ concentrations in five normal subjects after the oral administration of $100 \mu \mathrm{g} \mathrm{T}_{3}$. 


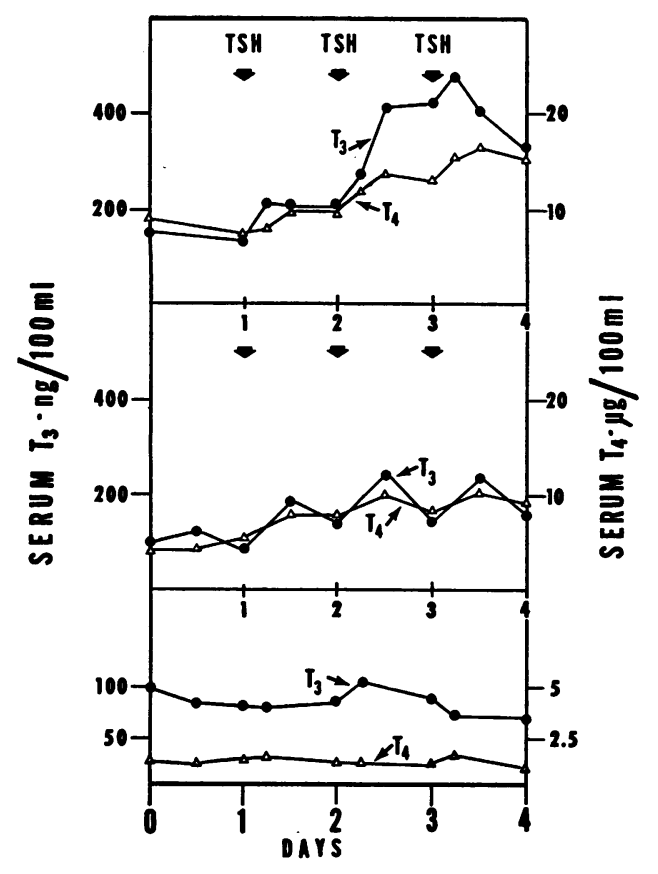

Figure 6 Serum $T_{3}$ and $T_{4}$ concentrations in three patients after the repeated intramuscular administration of 10 IU bovine TSH. The patients shown in the upper two panels had "hot" nodules of the thyroid (without hyperthyroidism); the third patient had primary hypothyroidism.

$100 \mathrm{ml} 8 \mathrm{hr}$ after $\mathrm{T}_{3}$ in one subject and $1,100 \mathrm{ng} / 100 \mathrm{ml}$ at $6 \mathrm{hr}$ in the other.

Results of serum $T_{3}$ and $T_{4}$ assays in three patients before and after the intramuscular administration of bovine TSH are shown in Fig. 6. Two of the patients had single functioning thyroid nodules and were euthyroid; the TSH was given to determine the functional capacity of the adjacent thyroid tissue. Post-TSH thyroid scans showed increased ${ }^{181} \mathrm{I}$ uptake in the extranodular thyroid tissue in both patients. In each of these patients, serum $T_{3}$ and $T_{4}$ concentrations increased subsequent to TSH administration. It is apparent that the serum $\mathrm{T}_{3}$ concentrations increased to higher levels and returned toward control more quickly than did the $\mathrm{T}_{4}$ concentrations. In the third subject, who had primary hypothyroidism and an elevated TSH level, the serum $\mathrm{T}_{3}$ concentration did not change.

Studies on the stability and extraction of $T_{s}$ in serum. Storage of serum at $5^{\circ} \mathrm{C}$ for 7 days did not lead to significant reduction in the measured $\mathrm{T}_{3}$ concentration. The $\mathrm{T}_{3}$ concentration of 10 serum samples so treated averaged $91.7 \%$ (range $83.1-112.8 \%$ ) of that found in paired samples stored at $-5^{\circ} \mathrm{C}$.

Analysis of the fractions prepared by column chromatography on Dowex AG $50 \mathrm{~W}-\mathrm{X} 2$ (Dow Chemical Co., Midland, Mich.) revealed the following results. In the nine instances in which serum was fractionated by this technique, the initial fraction containing unabsorbed protein and ammonium acetate contained no detectable $\mathrm{T}_{3}(<60 \mathrm{ng} / 100 \mathrm{ml})$. The $\mathrm{NH}_{4} \mathrm{OH}$ eluates of these sera contained $30.2-85.3 \%$ (mean $61.2 \%$ ) of the $\mathrm{T}_{3}$ concentration found in simultaneously assayed unextracted serum. Recovery of added $\mathrm{T}_{3}(100 \mathrm{ng} / 100 \mathrm{ml})$ averaged $61.0 \%$ in two experiments.

The ethanol extraction studies yielded similar results. The reconstituted ethanol precipitates did not inhibit the binding of $\mathrm{T}_{3{ }^{2}}{ }^{125} \mathrm{I}$ to anti- $\mathrm{T}_{3}$ serum. The ethanol supernatants contained from 36.0 to $79.5 \%$ (mean $65.5 \%$, $\mathrm{n}=30$ ) of the $\mathrm{T}_{3}$ concentration found in the unextracted serum samples. Recovery of $\mathrm{T}_{3}(50$ and $100 \mathrm{ng} / 100 \mathrm{ml}$ ) added to serum in 13 instances averaged $75.6 \pm 11.2 \%$ (SD). These results corroborate those described previously indicating substantial loss $(26.0 \%)$ of $\mathrm{T}_{3^{-}}{ }^{205} \mathrm{I}$ added to serum before extraction by binding to particulate material in the ethanol supernatants and indicate that endogenous $T_{3}$ is lost in a similar manner.

It is clear that extraction of $T_{3}$ from serum by these two methods effectively removed all of the serum material capable of inhibiting the binding of $\mathrm{T}_{{ }_{3}{ }^{125} \mathrm{I}}$ to antibody. Furthermore, the proportion of added $\mathrm{T}_{3}$ recovered was generally similar to the proportion of $T_{3}$ found in the serum extracts compared to that found in extracted serum samples.

\section{DISCUSSION}

The studies described herein clearly demonstrate that highly specific anti- $T_{3}$ serum of suitable affinity for the detection of subnanogram quantities of unlabeled $\mathrm{T}_{3}$ can be prepared readily. It seems clear from the data presented that the specificity of the antibody is directed primarily to the phenolic ring constituents of the thyronine molecule. Of the compounds studied, all having substantial reactivity with the antibody were $3^{\prime}, 3,5$-triiodinated analogues. This finding was not unsuspected since it is likely that the linkage of $\mathrm{T}_{3}$ to BSA was accomplished by formation of peptide bonds between the alanine side chain of $T_{3}$ and BSA (24). Stereospecificity was minimal since $D_{-} T_{3}$ reacted with the anti- $T_{3}$ serum almost as well as did L-T 3 . The nature of the slight reactivity of the tetraiodinated derivatives with the anti- $\mathrm{T}_{3}$ antibody bears special comment. The gel filtration data presented suggest that, at least in the case of $T_{4}$, most of the reactivity of the $T_{4}$ preparations studied was due to contamination with $T_{3}$ and even the slight reactivity $(0.01 \%)$ of the twice purified $\mathrm{T}_{4}$ could still reflect $T_{3}$ contamination. It seems reasonable to conclude that much of the reactivity of other tetraiododerivatives tested was due to contamination with their triiodo-analogues as well. 
The preparation of anti- $\mathrm{T}_{\mathrm{s}}$ antibody of high specificity has been reported by other workers (12-15). Using a similar coupling procedure, Gharib, Mayberry, and Ryan have prepared an anti- $T_{3}$ serum with characteristics much like those of the antisera described in this study (13). Antisera of high, though varying, specificity have been obtained also after immunization with $\mathrm{T}_{3}$-polylysine conjugates (12) and thyroglobulin (15).

The data presented strongly suggest that this radioimmunoassay reliably measures $T_{3}$ in serum. This was achieved only with the use of diphenylhydantoin, which serves both to inhibit binding of $\mathrm{T}_{3^{-}}{ }^{125} \mathrm{I}$ to serum $\mathrm{TBG}$ and to displace endogenous $T_{3}$ from TBG. If the latter was not the case both low serum $\mathrm{T}_{3}$ concentrations and poor recovery of added $\mathrm{T}_{3}$ would be expected. Neither was found. While there is controversy concerning the degree of in vivo binding of $\mathrm{T}_{3}$ to $\mathrm{TBG}$ (25-28), binding of $T_{3}$ to $T B G$ in vitro is readily demonstrable though the relative affinity of $\mathrm{T}_{3}$ for $\mathrm{TBG}$ varies from $1 / 3$ to $1 / 30$ of that of $T_{4}$ in different systems $(20,23,29)$. Diphenylhydantoin is a weaker competitive inhibitor of the $T_{4}-T B G$ reaction than is $T_{3}$, but it would be expected to inhibit the binding of $\mathrm{T}_{3}$ to $\mathrm{TBG}$ and displace $\mathrm{T}_{3}$ from TBG more effectively than it would alter $T_{4}-T B G$ interaction. The studies presented suggest that the binding of both $T_{3-}{ }^{125} \mathrm{I}$ and unlabeled $T_{3}$ to $T B G$ was completely inhibited by diphenylhydantoin. Whether significant quantities of endogenous $T_{4}$ were displaced from TBG by the quantity of diphenylhydantoin used in this system is not known. However, since added $T_{4}$ did not alter measured serum $T_{3}$ values, they should not be affected by endogenous $T_{4}$ displaced from TBG even if such displacement did occur. The fact that diphenylhydantoin in buffer solution did not inhibit the $\mathrm{T}_{3{ }^{125}} \mathrm{I}-$ anti- $T_{3}$ reaction, whereas it does alter $T_{3}$ (and $T_{4}$ ) binding to TBG, provides further evidence that the binding sites for these two reactions differ substantially.

The possibility that the presence of other $\mathrm{T}_{3}$ binding proteins in serum might influence these results also bears consideration. Such a phenomenon might influence $T_{3}$ assay results in several ways. In the first place, $\mathrm{T}_{3^{-}}{ }^{125} \mathrm{I}$ could become bound and thus unavailable for binding to anti- $\mathrm{T}_{3}$ antibody. This would result in overestimation of serum $\mathrm{T}_{3}$ levels. Endogenously bound $\mathrm{T}_{3}$ or $\mathrm{T}_{3}$ displaced from TBG by diphenylhydantoin could bind to this protein (s) and thus the serum $\mathrm{T}_{3}$ level would be underestimated. $T_{3}$ does not bind to thyroxine binding prealbumin $(23,30,31)$. $\mathrm{T}_{3}$ binding to albumin is weak and easily interrupted by a variety of materials $(23,31-34)$. The high affinity of the antibody for $T_{3}$ would appear to render this possibility unlikely.

The validity of the assay is also supported by the finding that the recovery of $\mathrm{T}_{3}$ added in a wide range of concentrations and to sera of varying endogenous $T_{3}$ and $T$. concentrations was excellent. Furthermore, all of the immunoreactive material present in serum could be removed by procedures known to extract much or all of the endogenous $T_{3}$. Finally, when $T_{3}$ was added to serum which was subsequently extracted by two methods, the recovery of $\mathrm{T}_{3}$ added in vitro approximated the proportion of endogenous $T_{3}$ found in serum extracts compared to that in unextracted serum. All of these observations strongly suggest that all of the endogenous $T_{3}$ in serum is made available to the antibody in the course of the reaction.

The serum $\mathrm{T}_{3}$ concentration results found with this technique differ somewhat from those previously reported. In general, procedures employing column and paper chromatography coupled with displacement analysis have yielded substantially higher values. For example, Sterling and coworkers found a mean serum $\mathrm{T}_{3}$ concentration of $220 \mathrm{ng} / 100 \mathrm{ml}$ (8), and a mean normal $\mathrm{T}_{3}$ value of $243 \mathrm{ng} / 100 \mathrm{ml}$ was recently reported by Wahner and Gorman using a similar technique (11). Larsen, using a modification of this procedure, found a mean normal $\mathrm{T}_{3}$ concentration of $180 \mathrm{ng} / 100 \mathrm{ml}$ (9). Mean normal $\mathrm{T}_{3}$ concentrations of $300 \mathrm{ng} / 100 \mathrm{ml}$ or more were reported by other investigators using a variety of techniques $(6,7,10)$. Little data is available as yet concerning radioimmunoassay measurements of serum $T_{3}$, but preliminary reports of values both greater and similar to those described here have recently appeared (14, $15,35)$. Inadequate separation of $T_{3}$ and $T_{4}(9,36)$, in vitro deiodination of $T_{4}(9,36)$ or formation of $T_{4}$ esters during extraction (37) are likely explanations for the finding of higher $\mathrm{T}_{3}$ values in the assays employing various types of chromatography. Possible sources of error in the radioimmunoassay measurements were discussed in preceding paragraphs.

As noted by others, elevated serum $T_{3}$ concentrations were found in almost all hyperthyroid patients studied. Only one such patient in this group had a serum $T_{3}$ concentration within the normal range. In hypothyroid patients, on the other hand, a substantial number had serum $\mathrm{T}_{3}$ concentrations within the normal range although the mean values for the two groups differed significantly $(P<0.001)$. All of these patients had some symptoms and signs compatible with the diagnosis of hypothyroidism and low serum $T_{4}$ and low or elevated TSH concentrations. Similar findings have been reported by Wahner and Gorman (11). Thus a near normal $T_{3}$ concentration alone is not sufficient to sustain the euthyroid state or prevent increased TSH secretion. The normality of the $T_{3}$ concentrations in some of these patients could in part be explained by the ability of high $\mathrm{TSH}$ levels to preferentially stimulate thyroidal release of $T_{3}$ (38). Greater increments in $T_{3}$ than in $T_{4}$ concentrations were also observed after exogenous TSH ad- 
ministration in two patients in this study. In addition, when there is $T_{4}$ deficiency undoubtedly relatively more $\mathrm{T}_{3}$ is bound to TBG than is normally the case (34). This could also explain why patients treated with sufficient $T_{3}$ to restore TSH levels to normal almost always had elevated serum $T_{3}$ concentrations.

Rapid changes in serum $T_{3}$ concentrations were observed when serial measurements were made after single oral doses of $100 \mu \mathrm{g} \mathrm{T}_{3}$. The similarity of the peak $\mathrm{T}_{3}$ levels suggest that fractional absorption varied little among the subjects. The wide variation in serum $T_{3}$ levels found in the $T_{3}$-treated patients (Table VII) can thus be explained by the fact that in those subjects blood sampling was not carried out at a fixed time after the previous dose of $T_{3}$. Rapid, and virtually complete, absorption and disappearance of isotopically labeled $T_{3}$ has been reported by Hays (39). In the studies described herein, the mean peak increment in serum $\mathrm{T}_{3}$ levels was $299 \mathrm{ng} / 100 \mathrm{ml}$. Assuming the volume of distribution of $\mathrm{T}_{3}$ to be 40 liters $(40,41)$, this increment would reflect the absorption of $119 \mu \mathrm{g} \mathrm{T}$, a value in reasonable agreement with the $100 \mu \mathrm{g}$ that was in fact administered. These results thus validate, by quite different methods, the previously published estimates of the degree of absorption and volume of distribution of $T_{3}$.

In hypothyroid patients receiving replacement therapy with thyroxine, normal or moderately elevated $T_{3}$ concentrations were found. The latter occurred largely in the patients receiving $300 \mu \mathrm{g} \mathrm{T}_{4}$ daily and the elevations observed were modest. Considerably higher $\mathrm{T}_{3}$ levels in patients receiving this dose of $T_{4}$ were reported by Braverman, Ingbar, and Sterling (2), but the $T_{s}$ assay employed (8) yields higher values probably because of in vitro $T_{4}$ deiodination and inadequate separation of $T_{3}$ and $T_{4}(9,36)$. While values before and during such treatment have been reported for only one patient in the present study, there seems little doubt that these results confirm those of Braverman and coworkers indicating there is peripheral conversion of exogenously administered $T_{4}$ to $T_{3}$ in human subjects.

\section{ACKNOWLEDGMENTS}

This work was supported in part by Grants T01 AM 05649, R01 AM 14039, RR 05415, and RR-40 (Clinical Research Center) from the U. S. Public Health Service. The authors are grateful to Mrs. Ann Rosenkranz for expert technical help and Mrs. Elaine Paolini for her secretarial assistance.

\section{REFERENCES}

1. Gross, J., and R. Pitt-Rivers. 1952. The identification of $3,5,3^{\prime}$-triiodothyronine in human plasma. Lancet. 1: 439.

2. Braverman, L. E., S. H. Ingbar, and K. Sterling. 1970. Conversion of thyroxine $\left(T_{4}\right)$ to triiodothyronine $\left(\mathrm{T}_{3}\right)$ in athyreotic human subjects. J. Clin. Invest. 49: 855 .
3. Sterling, K., M. A. Brenner, and E. S. Newman. 1970. Conversion of thyroxine to triiodothyronine in normal human subjects. Science (Washington). 169: 1099.

4. Pind, K. 1957. Paper chromatographic determination of thyroid hormone $\left(3,5,3^{\prime}\right.$-triiodothyronine) in serum without radio-iodine. Acta Endocrinol. 26: 263.

5. Maclagen, N. F., C. H. Bowden, and J. H. Wilkinson. 1957. The metabolism of thyroid hormones. II. Detection of thyroxine and triiodothyronine in human plasma. Biochem. J. 67: 5 .

6. Nauman, J. A., A. Nauman, and S. C. Werner. 1967. Total and free triiodothyronine in human serum. J. Clin. Invest. 46: 1346.

7. Hollander, C. S. 1968. On the nature of the circulating thyroid hormone: clinical studies of triiodothyronine and thyroxine in serum using gas chromatographic methods. Trans. Ass. Amer. Physicians Philadelphia. $81: 76$.

8. Sterling, K., D. Bellabarba, E. S. Newman, and M. A. Brenner. 1969. Determination of triiodothyronine concentration in human serum. J. Clin. Invest. 48: 1150.

9. Larsen, P. R. 1971. Technical aspects of the estimation of triiodothyronine in human serum: evidence of conversion of thyroxine to triiodothyronine during assay. Metab. (Clin. Exp.) 20:609.

10. Hagen, G. A., L. I. Diuguid, B. Kliman, and J. B. Stanbury. 1970. Double isotope derivative assay of serum triiodothyronine $\left(\mathrm{T}_{3}\right)$. Clin. Res. 18: 602. (Abstr.)

11. Wahner, H., and C. A. Gorman. 1971. Interpretation of serum triiodothyronine levels measured by the Sterling technique. N. Engl. J. Med. 284: 225.

12. Brown, B. L., R. P. Elkins, S. M. Ellis, and W. S. Reith. 1970. Specific antibodies to triiodothyronine hormone. Nature (London). 226: 359.

13. Gharib, H., W. E. Mayberry, and R. J. Ryan. 1970. Radioimmunoassay for triiodothyronine: a preliminary report. J. Clin. Endocrinol. Metab. 31 : 709.

14. Gharib, H., W. E. Mayberry, and R. J. Ryan. 1970. Determination of triiodothyronine concentration in human serum by radioimmunoassay. J. Lab. Clin. Med. 76: 863. (Abstr.)

15. Chopra, I. J., J. C. Nelson, D. H. Solomon, and G. H. Beall. 1971. Production of antibodies specifically binding triiodothyronine and thyroxine. J. Clin. Endocrinol. $M e-$ tab. 32 : 299.

16. Lowry, O. H., N. J. Roseborough, A. L. Farr, and R. J. Randall. 1951. Protein measurement with Folin phenol reagent. J. Biol. Chem. 193: 265.

17. Mougey, E. H., and J. W. Mason. 1963. Separation of some iodoamino acids and iodide by gel filtration. Anal. Biochem. 6: 223.

18. Murphy, B. E. P. 1965. The determination of thyroxine by competitive protein-binding analysis employing an anion-exchange resin and radiothyroxine. J. Lab. Clin. Med. 66: 161 .

19. Odell, W. D., J. F. Wilber, and R. D. Utiger. 1967. Studies of thyrotropin physiology by means of radioimmunoassay. Recent Progr. Hormone Res. 23: 47.

20. Murphy, B. E. P. 1969. Protein binding and the assay of non-antigenic hormones. Recent Progr. Hormone Res. 25: 563.

21. Wolff, J., M. E. Standaert, and J. E. Rall. 1961. Thyroxine displacement from serum proteins and depression of serum protein-bound iodine by certain drugs. J. Clin. Invest. 40: 1373.

22. Oppenheimer, J. H., and R. R. Tavernetti. 1962. Displacement of thyroxine from human thyroxine-binding 
globulin by analogues of hydantoin. J. Clin. Invest. 41: 2213.

23. Robbins, J., and J. E. Rall. 1967. The iodine-containing hormones. In Hormones in Blood. C. H. Grey and A. L. Bacharach, editors. Academic Press, Inc., New York. 2nd edition. 1: 383 .

24. Likhite, V., and A. Sehon. 1967. Protein-protein conjugation. In Methods in Immunology of Immunochemistry. C. A. Williams and M. W. Chase, editors. Academic Press, Inc., New York. 1: 150.

25. Zaninovich, A. A., H. Farach, C. Ezrin, and R. Volpe. 1966. Lack of significant binding of L-triiodothyronine by thyroxine binding globulin in vivo demonstrated by acute disappearance of ${ }^{181}$ I-labeled triiodothyronine. $J$. Clin. Invest. 45: 1290.

26. Zaninovich, A., R. Volpe, and C. Ezrin. 1969. Effects of variations of thyroxine-binding globulin capacity on the disappearance of triiodothyronine from the plasma. J. Clin. Endocrinol. Metab. 29: 1601.

27. Musa, B. U., R. S. Kumar, and J. T. Dowling. 1969. Role of thyroxine-binding globulin in the early distribution of thyroxine and triiodothyronine. J. Clin. Endocrinol. Metab. 29: 667.

28. Woeber, K. A., E. Hecker, and S. H. Ingbar. 1970. The effects of an acute load of thyroxine on the transport and peripheral metabolism of triiodothyronine in man. J. Clin. Invest. 49: 650.

29. Hao, Y., and M. Tabachnick. 1971. Thyroxine-protein interactions. VII. Effect of thyroxine analogs on the binding of ${ }^{125}$ I-thyroxine to highly purified human thyroxine-binding globulin. Endocrinology. 88: 81 .

30. Braverman, L., and S. H. Ingbar. 1965. Binding of 3,5, 3 '-triiodothyronine in human serum during agar gel electrophoresis at $\mathrm{pH}$ 7.4. Endocrinology. 76: 547.

31. Britton, A., B. R. Webster, C. Ezrin, and R. Volpe. 1965. The association of $\mathrm{I}^{131}$-labelled thyroxine and tri- iodothyronine with serum proteins after starch gel electrophoresis. Can. J. Biochem. 43: 1477.

32. Tabachnick, M. 1964. Thyroid-protein interactions. I. Binding of thyroxine to human serum albumin and modified albumins. J. Biol. Chem. 239: 1242.

33. Sterling, K. 1964. Molecular structure of thyroxine in relation to its binding by human serum albumin. $J$. Clin. Invest. 43: 1721.

34. Mitchell, M. L., A. H. Bradford, and S. Collins. 1964. Differences in the interaction of triiodothyronine- ${ }^{131} \mathrm{I}$ with serum proteins in vitro. J. Clin. Endocrinol. Metab. $24: 867$.

35. Mitsuma, T., N. Nihei, M. C. Gershengorn, and C. S. Hollander. 1971. Serum triiodothyronine in man: measurements by radioimmunoassay and gas chromatography. Clin. Res. 19: 377. (Abstr.)

36. Fisher, D. A., and J. H. Dussault. 1971. Contribution of methodological artifacts to the measurement of $T_{3}$ concentration in serum. J. Clin. Endocrinol. Metab. 32: 675.

37. Bellabarba, D., and K. Sterling. 1969. Formation of esters of thyroxine and triiodothyronine during alcoholic extraction. J. Clin. Endocrinol. Metab. 29: 1510.

38. Greer, M. A., Y. Grimm, and H. Studer. 1968. Qualitative changes in the secretion of thyroid hormones induced by iodine deficiency. Endocrinology. 83: 1193.

39. Hays, M. T. 1970. Absorption of triiodothyronine in man. J. Clin. Endocrinol. Metab. 30: 675.

40. Surks, M. I., and J. H. Oppenheimer. 1969. Formation of iodoprotein during the peripheral metabolism of 3,5 , 3 -triiodo-L-thyronine in the euthyroid man and rat. $J$. Clin. Invest. 48: 685.

41. Woeber, K. A., R. J. Sobel, S. H. Ingbar, and K. Sterling. 1970. The peripheral metabolism of triiodothyronine in normal subjects and patients with hyperthyroidism. J. Clin. Invest. 49 : 643. 